\title{
Supplement to Grundtvig-Studier 1972
}

Holger Kjar: Højskolens Grund. Kolding 1971, 139 pages, 32 kr. 20 øre. Reviewed by William Michelsen. (Grundtvig-Studier 1972).

The purpose of this book is, according to the preface, to see Grundtvig's idea of the folk high school as "a contribution to a European debate", but judging from the execution, the intention is to see it within the context of the history of ideas, ranking in importance with Plato's Academy and St. Benedict's monastic rule. What interests Holger $\mathrm{Kjær}$ is Grundtvig's vision of popular education and scholarship, kept completely separate but nevertheless based on a common view of man; a vision which is expressed most clearly in the work: "Om Nordens videnskabelige Forening" (1839). The idea expressed here of a Scandinavian university at Gothenburg has never been realized, but nevertheless the author cites a number of speeches made by prominent high school men, who do not seem to have understood what this idea really was.

Holger Kjær calls Grundtvig's university a "revolution". The strangest thing about it from a Grundtvigian viewpoint is that a sharp distinction is explicitly made between research and popular education. The model is provided by the colleges at Oxford and Cambridge, "where scholars by the hundred spend their days in the company of their equals (fellows)". These must, according to Grundtvig, be imitated wherever there is to be any question of a "scholarly life". Holger Kjær rightly compares Grundtvig's vision to the work at the Institute of Theoretical Physics in Niels Bohr's time.

The strangest thing from a scholarly viewpoint is however the view of man, that was to be the point of departure for the work at this university. Here Kjær compares Grundtvig's view of man (in Nordic Mythology 1832) with that of Irenaeus (in Adversus haereses) and of Luther (in De Servo Arbitrio), a comparison which is a great incitement to further study, as the given quotations unquestionably support the writer's opinion that Grundtvig builds directly upon Irenaeus and Luther. In this connection the book contains a number of critical comments on Kaj Thaning's thesis "First a man ..." (1964).

To Holger Kjær it looks as though it is still positivism which is the principal opponent of Grundtvigian scholarship. But when one realizes that no branch of knowledge is without its basic assumptions, the situation becomes different from what it was when Grundtvig was alive and during the first hundred years after his death. Then Grundtvig's anthropology can in fact be regarded as an alternative to the theory of knowledge that, without further proof, considers the materialistic view of history and human life the only true one. And Holger Kjær's book is a valuable contribution to the characterization of Grundtvig's view of man and its position in the history of European ideas. 
Ebbe Klovedal Reich: Frederik. A popular book about the life and times of N. F. S. Grundtvig. Reviewed by Gustav Albeck. (Grundtvig-Studier 1972).

People's interest has quite justifiably been aroused by the fact that a young left-wing writer has in the centenary year of Grundtvig's death, attempted to give his people a work about him which, despite its one-sidedness and political subsidiary motives, shows that Grundtvig even now has something to say to his fellow-countrymen.

The author has, however, by employing the term: "popular book", dissociated himself to a certain extent from scholarship. He keeps very close to F. Rønning's now rather antiquated biography and to Thyra Jensen's books about Constance Leth and the women in Grundtvig's life, but seems, with the exception of Thaning's thesis, to have avoided the more important works of first-hand research. Several of the passages in his book tend towards fiction. It could be compared to the biographies that flourished in the 1930's and which were especially of English authorship, or to the so-called documentary novel of our own age. The danger with the documentary part - e.g. the excellent pictorial material - is that the reader is tempted to believe that the whole book is just as reliable as these objective elements. It is not.

It not only contains errors due to pure carelessness, but also cites Grundtvig in support of modern revolutionary movements. The reviewer admits that there were certain features here, worthy of closer consideration. They are presented in a series of introductory sections ("prefaces"), among which the reviewer singles out the one about the poet and the one dealing with his faith. Ebbe Reich writes about Grundtvig because he had a firmness of faith that both revolts and attracts him. He maintains that God is alien to modern society, which seems to be going to rack and ruin. "Grundtvig's voice," he says "was for me like the voice of one crying in the wilderness. It made me listen, wonder, doubt, believe and see dimly. Just as life does, when it turns out to be greater than we had realized." Thus the reader is vouchsafed occasional glimpses of a living Grundtvig.

There were many women in Grundtvig's life, the most interesting of them being Clara Bolton, whom Grundtvig met at a party in England - and whom he never saw again. She seems to have been responsible for the bard's freer view of woman as a fellow-being and source of inspiration, and for his new profession of faith in our Greek heritage. She has been counted among Disraeli's mistresses, but in the most recent biographies there has been a move towards a cautious reappraisal of her reputation. A collection of unpublished letters would rather suggest an idealistic admirer and muse. This is what she also came to represent for Grundtvig. Although we have Grundtvig's word for it that they never met again, Reich uses the episode for a long erotic passage according to the conventional pattern of today - in order to make Grundtvig as human as possible. But it makes the picture of him "unhistorical".

The book is well-written and in some places entertaining, in others deeply moving, where the author's commitment appeals to the poetic forces within him. 